\title{
Protein S Deficiency Presenting with Hemorrhage in a Term Neonate
}

Fairouz Ayari*, Takoua Bensmail, Essid Latifa, Wiem Barbaria and Samia Kacem

Neonatology Intensive Care Unit of the Maternity and Neonatology Center, Tunis, Tunisia

\begin{abstract}
Unexplained bleeding symptoms in otherwise healthy full-term usually present a diagnostic challenge for treating physicians requiring prompt and accurate laboratory investigations to ensure appropriate treatment and possibly avoid long-term morbidity. We report a case of a term neonate with severe protein $S$ deficiency manifested by systemic hemorrhage and multiple organ failure at 9 days of age. We review how protein $S$ influences the coagulation and the fibrinolytic pathways, discussing therapeutic approaches of neonates with purpura fulminans.
\end{abstract}

Keywords: Protein S deficiency; Blood sample; Thrombophilic disorder

\section{Introductio}

Protein S (PS) is an antithrombotic plasma protein that acts mainly as a cofactor of activated protein $\mathrm{C}$ (APC) anticoagulant activity in the degradation of factor Va and activated factor VIII [1]. PS circulates in plasma in two forms. Approximately $60 \%$ is bound non-covalently to complement component $\mathrm{C} 4 \mathrm{~b}$ binding protein $\mathrm{b}$-chain $(\mathrm{C} 4 \mathrm{BP})$, whereas the remaining $40 \%$ is free [2]. Only free PS possesses APC cofactor activity [3]. PS deficiency is an infrequent but severe hereditary autosomal dominant thrombophilic disorder. Protein S deficiency may also be acquired [4]. Main symptoms of PS deficiency are superficial thrombophlebitis, deep venous thrombosis and pulmonary emboli [5]. According to Gomez et al. homozygous PS deficiency is related to abortion or postpartum presentation with purpura fulminans [6]. In the present study we describe a case of a term neonate with severe PS deficiency who had intraventricular hemorrhage (IVH) since the age of 9 days.

\section{Case Report}

After an uneventful pregnancy, a 34-year-old woman (gravida 2, para 2, Blood group $\mathrm{O}^{+}$), with a healthy first baby has delivered in 2016 a term female infant with 39 week of gestational age by vaginal delivery. The newborn Apgar score in ten minutes after delivery was 7 , the newborn weight was $3500 \mathrm{~g}$. The mother was hospitalized in an adult resuscitation department for thrombosis of the common femoral vein extending to the iliac vein, which is complicated by distal pulmonary embolism in postpartum, confirmed by the thoracic angioscanner. Because of progression of jaundice at the $9^{\text {th }}$ day of life baby was admitted in the Neonatology Center in year 2016. The examination at admission showed: intense jaundice, pallor, the rest of the examination showed no abnormalities especially no hepatomegaly, no splenomegaly, no serosanguine bump and a perfect neurological state. The results of the initial blood sample showed anemia, thrombocytopenia with a blood clot not confirmed by another screening, a negative direct coombs test (DCT), Blood group $\mathrm{A}^{+}$, total bilirubin/direct 320/35 $\mu \mathrm{mol} / \mathrm{L}, \mathrm{C}$-reactive protein level (CRP) $3 \mathrm{mg} / \mathrm{L}$. The initial diagnosis was hemolytic jaundice by alloimmunization in the $\mathrm{ABO}$ system and then the newborn was put on phototherapy. A few hours later the newborn was transferred to the Neonatal Intensive Care Unit because of seizures and hemorrhagic shock (presence of a large ecchymosis at the point of sampling and purpuric lesions on the anterior surface of the trunk, heart rate 220/min, hematocrit (HCT) $20.4 \%, \mathrm{Hb} 6.9 \mathrm{mg} / \mathrm{dl}$ ).

First line treatment consists of endotracheal intubation, sedation and ventilation in high frequency oscillation mode, volume resuscitation with $20 \mathrm{ml} / \mathrm{kg}$ bodyweight (BW) saline solution and, after blood sampling, intravenous administration of $10 \mathrm{mg}$ vitamin $\mathrm{K}, 20$ $\mathrm{ml} / \mathrm{kg}$ BW fresh frozen plasma, $20 \mathrm{ml} / \mathrm{kg}$ BW packed red blood cells (5 transfusion cycles), $20 \mathrm{mg} / \mathrm{kg}$ BW Phenobarbital and vasoactive drugs. Cerebral ultrasound revealed intraventricular haemorrhage, abdominal ultrasound showed splenic hemorrhage and cardiac ultrasound showed a floating intracardiac thrombus. Disseminated intravascular coagulation test showed no abnormalities (Fibrinogen normal, Fibrinogen and Fibrin Degradation Products (FDP) normal, $\mathrm{D}$-dimers normal), vitamin $\mathrm{K}$ deficiency dependent bleeding could be excluded because of normal age-related level of vitamin $\mathrm{K}$ dependent Prothrombin (Factor II). Thrombophiliac screening revealed a severe protein S (PS) deficiency in the patient with a PS plasma activity $<10 \%$. This result agrees with that found in the mother whose Thrombophilia screening showed the same result. The newborn was dead by multivisceral failure even after transfusion and activated protein $\mathrm{C}$ concentrates infusion on the $15^{\text {th }}$ day of life.

\section{Discussion}

Vitamin K deficiency is the major cause of intracranial bleeding in term neonates and is considered first in any healthy term neonate with severe hemorrhage [7]. On the other hand, birth trauma, asphyxia and malformation of blood vessels should be considered in case of intracranial hemorrhage in term neonates. Thus the rate of unexplained cases remains up to $25 \%$ [8]. Wu et al. [9], have shown that of the 2,397 neonates who were at least 36 weeks gestation and admitted to the Intensive Care Nursery during the study period, $29(1.2 \%)$ neonates were identified with IVH and $9(31 \%)$ had cerebral sinovenous thrombosis. The latter is associated with thalamic haemorrage since clot formation in the deep venous structures can be accompanied by hemorrhage into the ventricles, because the deep venous system drains the choroidal, atrial, and thalamostriate veins [10]. Protein S deficiency is a hereditary congenital prothrombotic disorder presenting postnatally with purpura

*Corresponding author: Feirouz Ayari, Neonatology Intensive Care Unit of the Maternity and Neonatology Center, Tunis, 1110, Tunisia, Tel: 0021692035624; Email: ayarifeirouz@yahoo.fr

Received May 11, 2017; Accepted February 09, 2018; Published February 16, 2018

Citation: Ayari F, Bensmail T, Latifa E, Barbaria W, Kacem S (2018) Protein S Deficiency Presenting with Hemorrhage in a Term Neonate. Health Care Current Reviews 6: 219. doi: 10.4172/2375-4273.1000219

Copyright: (C) 2018 Ayari F, et al. This is an open-access article distributed unde the terms of the Creative Commons Attribution License, which permits unrestricted use, distribution, and reproduction in any medium, provided the original author and source are credited. 
fulminans in homozygous patients [6]. Sahriarian et al. [11] have reported the case of a term newborn with seizures, mobile masses in the IVC, IVH, and multiple thrombosis of portal vein due to decline in PS level. But then it appears that the protein S deficiency in this infant was temporary and as a result of A-V malformation. Fischer et al. [12] were the first to describe a newborn with homozygous qualitative PS deficiency who had a PS plasma activity $<10 \%$ and intracerebral massive bleeding without vascular malformations or sinovenous thrombosis neither on MRI nor in cerebral autopsy. But protein S deficiency may may be related to antiphospholipid antibodies, nephrotic syndrome, pregnancy, the puerperium, estrogen or warfarin use, or to DIC. Also, inflammation or infection, by increasing $\mathrm{C} 4 \mathrm{~b}$ binding protein levels, may reduce protein $S$ activity [4]. This is why; it is not obvious to determine the etiology of the protein $S$ deficiency in our case especially that the mother and the first baby were asymptomatic. For this we agree with Wu et al. who recommended that term neonates with IVH should undergo neuroimaging to evaluate the presence of sinovenous thrombosis [9]. Whatever the reason of IVH, First line treatment consists of circulatory support, volume resuscitation administration of fresh frozen plasma, platelet concentrate, packed red blood cells and vitamin $\mathrm{K}$ as described in our case. IVH is seen mainly in preterm neonates in the context of germinal matrix hemorrhage. In contrast, IVH in term neonates results primarily from hemorrhage in the choroid plexus or thalamus [13-15]. Petaja et al. [16] have conducted a study at the neonatal intensive care unit of the Hospital for Children and Adolescents, University of Helsinki and they have suggested that in very premature newborn IVH may be triggered by thrombophilic coagulation abnormalities and especially by Gln506-FV.

\section{Conclusion}

Acquired or hereditary protein S deficiency is a rare but lifethreatening disorder of coagulation. Mental outcomes vary widely for this pathology and depend on the severity of the intracranial insult. Infants who have suffered neonatal strokes may have normal outcomes, but they may also develop cerebral palsy, cognitive or visual impairment. Some of these complications may be inevitable, and prompt recognition and treatment of the underlying disease can optimize outcomes for these unique patients.

\section{References}

1. Walker FJ (1981) Regulation of activated protein $C$ by protein $S$. The role of phospholipid in factor Va inactivation. J Biol Chem 256: 11128-11131.

2. Dahlback B (2007) The tale of protein $S$ and C4b-binding protein, a story of affection. Thromb Haemost 98: 90-96

3. Dahlback B (1986) Inhibition of protein C cofactor function of human and bovine protein S by C4b-binding protein. J Biol Chem 261: 12022-12027.

4. Kate T, Van Der Meer J (2008) Protein S Deficiency: A Clinical Perspective. Hemophilia 14: 1222-1228.

5. Azarpeikan S, Hashemi A, Atefi A (2011) Lacunar infarction in child with Protein $S$ deficiency: A case report. Iran J Ped Hematol Oncol 1: 67-70.

6. Gomez E, Ledford MR, Pegelow CH, Reitsma PH, Bertina RM (1994) Homozygous Protein S deficiency due to a one base pair deletion that leads to an stop codon in exon III of the protein S gene. Thromb Haemost 7: 723-726.

7. Govaert P, Ramenghi L, Taal R, de Vries L, deVeber G (2009) Diagnosis of perinatal stroke I: definitions, differential diagnosis and registration. Acta Paediatr 98: 1556-1567.

8. Menkes JH, Sarnat HB (2006) Perinatal asphyxia and trauma: Intracranial hemorrhage. Child Neurol pp: 387-391.

9. Wu YW, Hamrick SE, Miller SP (2003) Intraventricular hemorrhage in term neonates caused by sinovenous thrombosis. Ann Neurol 54: 123-126.

10. Wu YW, Miller SP, Chin K (2002) Multiple risk factors in neonatal sinovenous thrombosis. Neurology 59: 438-440.

11. Sahriarian S, Akbari P, Amini E, Dalili H, Niknafs N, et al. (2016) Intraventricular Hemorrhage in a Term Neonate: Manifestation of Protein S Deficiency- A Case Report. Iran J Public Health 45: 531-534.

12. Fischer D, Porto L, Stoll H, Geisen C, Scheloesser RL (2010) Intracerebral mass bleeding in a term neonate: manifestation of hereditary protein $\mathrm{S}$ deficiency with a new mutation in the PROS1 gene. Neonatology 98: 337-340.

13. Lacey DJ, Terplan (1982) Intraventricular hemorrhage in full-term neonates. Dev Med Child Neurol 24: 332-337.

14. Roland EH, Flodmark O, Hill A (1990) Thalamic hemorrhage with intraventricular hemorrhage in the full-term newborn. Pediatrics 85: 737-742.

15. Volpe J (2001) Neurology of the newborn. J Paediatr Neurol 25: 1-3.

16. Petaja J, Hiltunen L, Fellman V (2001) Increased Risk of Intraventricular Hemorrhage in Preterm Infants with Thrombophilia. Pediatr Res 49: 45. 